A Siófoki Kórház-Rendelőintézet Sebészeti Osztály és Nagyatádi Kórház Sebészeti Osztály ${ }^{1}$, a Pécsi

Tudományegyetem Klinikai Központ Fogászati és Szájsebészeti Klinika, Pécs², a Somogy Megyei Kaposi

Mór Oktató Kórház Szájsebészeti Osztály, Kaposvár ${ }^{3}$ és a Clinic of Microsurgery and Reconstructive

Surgery of Upper Extremity, Institute of Traumatology and Orthopedics, NAMS Ukraine, Kiev közleménye

\title{
Thrombocyta gazdag plazmával kezelt perifériás idegrekonstrukció vizsgálata
}

\author{
patkányokon \\ DR. TÓTH ZOLTÁN¹, DR. FRANK DOROTTYA², DR. KOLAROVSZKI BÉLA,
}

DR. VASYL GAYOVICH ${ }^{4}$

Érkezett: 2014. december 16.

DOI: $10.21755 / \mathrm{MTO} .2015 .058 .0001 .006$

\section{ÖSSZEFOGLALÁS}

A tanulmány célja, hogy bizonyítsa a thrombocyta gazdag plazma hatását, a perifériás ideg autografttal való rekonstrukcióját követően, az idegregenerációra és az izom metabolizmusra, patkány modellen. A kísérletek négy csoporton történtek, egy kontrollcsoport mellett. Az első csoportban, a perifériás idegkárosodást az ischiadicus idegen végzett neurotomiával hozták létre. A második csoportban idegrekonstrukció történt, end-to-end epineuralis idegvarrattal. A harmadik csoportban az idegvarrat mellé thrombocyta gazdag plazma került beadásra, a negyedik csoportban a thrombocyta gazdag plazma mellett idegnövekedési faktort is alkalmaztak. A csoportok motoros funkcióinak vizsgálata 30 nappal a sérülést követően járásanalízis formájában történt (ischiadicus funkcionális index). A vázizmok biokémiai károsodásának meghatározására az aminosavak, zsírsavak és a kalcium metabolizmusának meghatározásával történt. A rekonstruált ideg szövettani vizsgálata is megtörtént. A nervus ischiadicus autografttal való rekonstrukciója részleges idegi regenerációt biztosít, amelynek eredményeképpen az eredeti funkció visszatér, és a biomechanikai eltérések csökkennek. Az idegregeneráció az idegvarrat 45,2\%-kal, növekedési faktor mellett 62,5\%-kal, thrombocyta gazdag plazma alkalmazása mellett $80 \%$-kal növekedett. A teljes fehérje szintézis $35,7 \%-31,9 \%-38,6 \%$-kal növekedett. A növekedési faktor és thrombocyta gazdag plazma alkalmazásával, az esszenciális aminosavak és zsírsavak szintézisének zavara csökkent, a kalcium metabolizmus pedig javult. A patkányokon, autografttal végzett perifériás idegrekonstrukciók során elért eredmények azt mutatják, hogy a thrombocyta gazdag plazma, növekedési faktorral együtt alkalmazva segíti a perifériás idegsérülést követő idegregenerációt, megelőzi az izomatrófiát, és meggyorsítja a neuromuscularis funkció visszanyerését.

\section{Kulcsszavak: $\quad$ Állatkísérlet; Autograft; Idegsérülés; Idegrekonstrukció; Thrombocyta gazdag plazma;}

Z. Tóth, D. Frank, B. Kolarovszki, V. Gayovich: Investigation of reconstruction of peripheral nerves treated with platelet rich plasma in rats

The aim of this study was to demonstrate the effects of PRP gel on nerve regeneration and muscle metabolism after peripheral nerve autografting in a rat model. Experiments were performed in four groups, with a control group. In a first group the nerve damage was performed with a sciatic nerve transection. In the second group end to end neurorhaphy was performed. In the third group with a sciatic nerve transection, autograft repair with the introduction of platelet-rich plasma, in the fourth group, in addition to the platelet rich plasma nerve growth factor was also used. Motor functional assessment of the groups was performed 30 days after injury using walking track analysis (sciatic functional index). Biochemical damage profiles of skeletal muscle include amino acids, fatty acids and calcium metabolism. Morphological and morphometric data were also analyzed. Sciatic nerve autografting provides partial nerve regeneration, functional recovery and reduces muscle biochemical disorders. The efficiency of nerve regeneration enhances by $45.2 \%$; NGF $-62.5 \%$; PRP gel -80.0 . Total protein synthesis increases according to $35.7 \%, 31.9 \%$ and $38.6 \%$. PRP gel and NGF suppress metabolic disruption of essential amino acids and fatty acids; affect calcium metabolism. Our results demonstrate that PRP, along with NGF, promotes the 
regeneration of peripheral nerve injuries, prevention of muscle atrophy and accelerates neuromuscular functional recovery in rat peripheral nerve autografting model.

Key words:

Animals; Autografts; Nerve regeneration;

Peripheral nerve injuries; Platelet-rich plasma;

\section{BEVEZETÉS}

A balesetek során gyakran keletkeznek perifériás idegsérülések. Ezen sérülések legsúlyosabb formája az ideg komplett sérülése, amely együtt járhat az idegek szakaszának hiányával, amelynek eredménye motoros és szenzoros funkció kiesése a sérülés helyétől distalisan (7, 18).

Napjainkban a perifériás ideghiányok pótlásának leggyakrabban alkalmazott kezelése és egyben „gold standard"-je a hiányzó idegszakasz autografttal való pótlása. A fent említett eljárásnak azonban számos hátránya is van, mint a limitált donorszövet (13) a másodlagos deformitások, a graft és a donorszövet közötti méretbeli és strukturális különbségek (22), illetve a graftnekrózis.

A kutatások arra irányulnak, hogy minél hatásosabb eljárásokat fejlesszenek ki az idegregeneráció hatékonyságának fokozására, hogy a szenzoros és motoros funkciók mielőbb visszatérjenek. Számos élettani és neurotop faktor, mint a gyógyszerek befolyásolják az idegregenerációt $(3,5,24,26,28)$.

A modern traumatológiában a sérült perifériás ideg- és így az autograft regeneráció egyik aktivátorának is tekintik a thrombocyta gazdag plazmát (platelet rich plasma=PRP). Kutatások kimutatták, hogy a thrombocyták számos olyan trophicus faktort szabadítanak fel, amelyek elősegítik az idegregenerációt és pozitiv hatásuk van az izomatrófia megelőzésében, köztük ilyen, az idegi növekedési faktor (nerve growth factor=NGF) $(1,6,8,9,11,12$, 19). Ez a tanulmány a PRP és az NGF kezelés hatását és az általa idegregenerációban és a hosszú ideje denervált vázizomzatban bekövetkező biokémiai változásokat mutatja be.

\section{ANYAG ÉS MÓDSZER}

\section{Kísérlethez használt állatok}

A kísérleteket 200-215 grammos Wistar Kyoto patkányokon végeztük. Az állatokat teljes kontrollált körülmények között $22 \pm 2$ ㄷ Con, $55 \pm 5 \%$ páratartalmon és $12-12$ órás világosság-sötétség napi cikiusian tartotiuk. Az állatok szabadon fogyaszthatták a hagyományos rágcsálótápot és a vizet. A sebészi beavatkozást megelőzően 12 órával felfüggesztettük a táplálást, de vizet szabadon fogyaszthattak. A kísérleti beavatkozásokat Bain szerint végeztük (2), az állatvédelmi Európai Konvenció szabályzatának betartása mellett (4).

\section{Kísérleti protokoll}

A kísérleti állatokat négy csoportba osztottuk:

I. Kontrollcsoport $(n=8)$;

II. csoport: nervus ischiadicus átmetszésen átesett állatok $(n=8)$;

III. csoport: nervus ischiadicus átmetszést követően autografttal történt idegrekonstrukción átesett egyedek $(n=8)$;

IV. csoport: nervus ischiadicus átmetszést követően autografttal történt idegrekonstrukció, PRP kezelésen is átesett csoport $(n=8)$;

V. csoport: nervus ischiadicus átmetszést követően autografttal történt idegrekonstrukció és NGF kezelésen is átesett csoport $(\mathrm{n}=8)$.

\section{Sebészi protokoll}

A patkányok natrium-thiopentállal lettek altatva $(40 \mathrm{mg} / \mathrm{kg}$, i. p.), amennyiben szükséges volt a dózist kiegészítettük. A sebészi feltárás a patkányok hátsó lábának középső harmadában történt, a szövetek között az ischiadicus ideget felkerestük és izoláltuk, az ideg átmetszését követően $1 \mathrm{~cm}$-es szakaszt eltávolítottunk. A későbbiekben eltávolított rész szolgált autograftként. Steril varróanyagot használva az eltávolított szakaszt 180 fokkal elforgatva, end-to-end epineuralis idegvarratot végeztünk ( $8 / 0$ atraumatikus szerelt prolene monofil varróanyagot használtunk, „Ethicon”). A sebet antibiotikus oldattal (penicillin) átöblítettük és varratokkal szorosan zártuk. 


\section{Kísérleti kezelés}

A thrombocyta gazdag plazmát közvetlenül a felhasználás előtt készítettük. Az állatok altatását az előző fejezetben leírt módon végzetük, majd Harms és Ojeda szerint a véna jugularis kanülálásával, minden állattól $3.5 \mathrm{ml}$

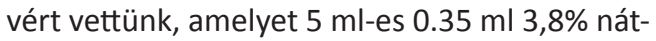
rium citrátot tartalmazó szilikon csőbe gyűjtöttünk (1:10) (16). A mintát $160 \mathrm{G}-\mathrm{vel}, 20$ percig centrifugáltuk 22ำ-on (Hettich Zentrifugen). Ekkor egy felső szalmasárga frakciót (szérum frakció) és egy alsó piros, a vörösvértesteket tartalmazó frakciót kapunk, a felső frakciót ismételten centrifugáljuk 400 G-vel 15 percig, amelynek eredményeképpen két komponenst kapunk, egy felső thrombocyta szegény, és egy alsó thrombocyta gazdag frakciót. Ezt a thrombocyta gazdag frakciót 1:0.15 arányban hígítottuk $100 \mathrm{U} / \mathrm{ml}$ thrombint (Sigma Aldrich) taratlmazó $10 \%$-os CaCl oldattal. A kapott mintában a thrombocyta koncentráció átlagosan nyolcszor magasabb volt, mint natív vérben

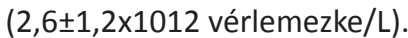

Az állatokba az end-to-end idegvarrat mellé helyileg $1 \mathrm{ml}$ thrombocyta gazdag plazmát és 0,4 $\mu \mathrm{g}$ patkány idegnövekedési faktort (NGF, Sigma-Aldrich Co.) injekcióztunk közvetlenül a beavatkozást követően egy alkalommal.

\section{Idegfunkció visszatérésének vizsgálata}

Kísérleti körülmények között a perifériás idegsérülés regenerációjának funkcionális vizsgálatára számos teszt áll rendelkezésünkre, attól függően, hogy a motoros beidegzést viszszatérését idegélettani szempontból szeretnénk vizsgálni, vagy az izomerőt, esetleg a viselkedési teszteket kívánunk végezni (28). Nervus ischiadicus sérülés esetén a lábnyom jelenti a viselkedési vizsgálatot, amelynek számszerüsítésére leggyakrabban az ischiadicus funkcionális indexet (SFI) használjuk $(2,26)$. Ez egy nem invazív, egyszerú vizsgáiat, arneíy aikalmas arra, hogy különböző, egymást meghatározott módon követő időpontokban alkalmazzuk.

A motoros funkció vizsgálata 30 nappal a sérülést követően járásanalízis formájában történt, Bain módszerének alapján (2) (ischiadicus funkcionális index). A patkányok hátsó lábát higított tintába mártottuk és az állatoknak egy csövön keresztül kellett áthaladniuk. A folyosó alján papírokat helyeztünk el, melyen áthaladva lábnyomokat rögzíteni tudtuk (1. ábra). Mértük a lábnyom hosszúságát ( $\mathrm{PL})$, a hüvelyk és a kisujj távolságát (TS) a középső ujj távolságát a másodiktól és a negyedik ujjtól, a kísérleti oldalon (EPL, ETS, EIT) és az ép oldalon (NTL, NTS, NIT). Az ischiadicus funkcionális indexet (SFI) a következő képlet alapján számoltuk:

$$
\mathrm{SFI}=-38.3(\mathrm{EPL}-\mathrm{NPL}) / \mathrm{NPL}+109.5(\mathrm{ETS}-
$$$$
\text { NTS }) / \text { NTS + 13.3(EIT-NIT)/NIT }-8.8=
$$$$
(-38.3 \times \text { PLF })+(109.5 \times T S F)+(13.3 \times \text { ITSF })-8.8
$$

Az SFI 0 értéke normál idegfunkcióra, míg a -100-as érték komplett diszfunkcióra utal.

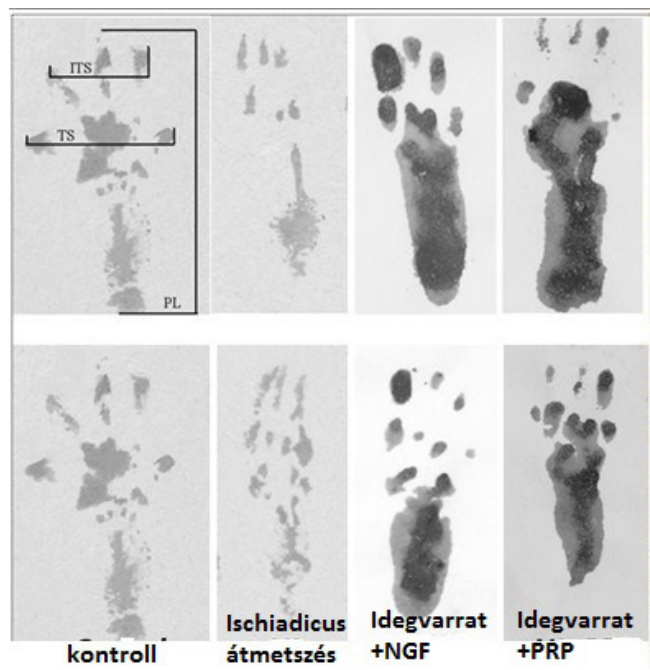

1. ábra Ischiadicus funkcionális index (SFI) a különböző csoportokban 


\section{Szövettan értékelés}

A sebészi beavatkozást követően egy hónappal minden csoportból a patkányokat letális dózisú nátrium-thiopental adásával túlaltattuk. A nervus ischiadicust idegből egy 20 mm-es szakaszt eltávolítottunk, úgy, hogy az tartalmazza a korábban rekonstruált idegszakaszt és attól proximalis és distalis irányban is egy szakaszt, majd szövettani előkészítést követően fénymikroszkóp alatt tanulmányoztuk. $15 \mu \mathrm{m}$-es hosszirányú idegmetszeteket készítettünk kriotom segítségével, majd ezüst impregnációt végeztünk.

\section{Mikroszkópos vizsgálat}

20x nagyítású mikroszkóppal számos színes mikro fotót készítettünk egy Olympus fénymikroszkóppal (Olympus BX 51) 20x nagyítással, színes RGB [Red, Green, Blue] objektívvel. A szövettani elemzést Carl Zeiss szoftver segítségével végeztük (AxioVision SE64 Rel.4.9.1).

\section{Izomszövet biokémiai elemzése}

A vázizomzat károsodás biokémiai vizsgálata, az aminosavak, a zsírsavak és az ásványi anyagok mennyiségében bekövetkező hirtelen változások kimutatását jelenti. Célunk ezen változások bizonyítása, az aminosavak, a zsírsavak, és a kalcium mennyiségének mérésén keresztül. A hátsó lábak izomszöveteit homogenizálva biokémiai tanulmányoknak vetettük alá. Az aminosavak meghatározását Moore szerint végeztük (20), a zsírsavak metabolizmusát gázkromatográfiával vizsgáltuk. A hátsó lábak izomszöveteinek teljes kalcium mennyiségének meghatározásához, azokat $450^{\circ} \mathrm{C}$ fokon elégettük, majd keletkező hamut $6 \mathrm{~N} \mathrm{HCl}$-ban feloldva, Perkin-Elmer 1100-B típusú készülékkel határoztuk meg (21).

\section{Statisztikai elemzés}

Minden számszerűsíthető adat az átlag \pm középérték közepes hibája (SEM). A kontroll és a kezeléson átesett cosportok közöt je. lentkező szignifikáns biokémiai eltéréseket non-parametric Mann-Whitney $U$ teszttel elemeztük. Az SFI indexekben és a nervus ischiadicus morfometrikus tulajdonságaiban jelentkező szignifikáns eltéréseket Student's teszttel határoztuk meg. A szignifikancia szintjét $p<0,05$ határoztuk meg.

\section{EREDMÉNYEK}

A nervus ischiadicus funkcionális regenerációjának vizsgálata

A ischiadicuson elvégzett idegvarratot követően az SFI átlagértéke $-59.2 \pm 4,3(p<0,001)$ volt, az idegi funkció komplett kiesését egyik esetben sem észleltük (SFI értéke ekkor megközelítőleg -100) (I. táblázat, 1. ábra). Az enyhe funkcionális javulást, az állatoknak a bénult végtaghoz való hozzászokása okozhatta. Az NGF-ral és a PRP-val kezelt csoportokban az SFI értékei szignifikánsan emelkedtek $-45.5 \pm 2.0$ $(p=0.003)$, és $-52.1 \pm 1.7(p=0.065)$, amely az NGF-fel kezelt esetekben 7-10\%-os funkcionális javulást jelent.

\section{I. táblázat Nervus ischiadicus funkcionális értékelése}

\begin{tabular}{|c|c|c|c|}
\hline \multicolumn{1}{|c|}{ Csoport } & $\begin{array}{c}\text { SFI index } \\
\text { (átlag } \pm \text { standard hiba) }\end{array}$ & Kontroll & *p-érték \\
\hline Kontrollcsoport & $-7,3 \pm 3,9$ & - & Idegvarrat \\
\hline Ischiadicus átmetszés & - & & \\
\hline Idegvarrat & $-59,2 \pm 4,3$ & $<0.001$ & 0.003 \\
\hline Idegvarrat+NGF & $-45,5 \pm 2,0$ & $<0.001$ & 0.065 \\
\hline Idegvarrat+PRP & $-52,1 \pm 1,7$ & $<0.001$ & \\
\hline *p-érték a Student's - teszt alapján & & & \\
\hline
\end{tabular}




\section{Nervus ischiadicus rekonstrukció}

A teljes axonalis sürüséget 30 nappal az ischiadicus átmetszését és autografttal való pótlását követően vizsgáltuk. A II. csoportban, az idegszakasz eltávolítását követően, regeneráció nem következett be, a proximalis csonk megmaradt, vagy poszttraumás neuroma alakult ki. A szövettani vizsgálatok a nervus ischiadicus autografttal való rekonstrukcióját követően aktív regenerációs folyamatokat mutattak ki (III. csoport). A proximalis és distalis idegvarrat területét a glia sejtek szabályos elrendeződése jellemezte. Az érstruktúrák és a glia elemek a poszttraumás neuromában és a distalis végben heterogének voltak, a neuromában az epineurinum megvastagodott, és számos érképletet tartalmazott (2. ábra). A regeneratív neuromában és a distalis szakaszon számos olyan részt találtak, ahol a regeneráció nem volt megfelelő, ezekre a területekre szövettanilag tömött rostos kötőszövet, gliákból álló hegszövet és számos visszaforduló idegrost volt jellemző. Az átlagos axonsűrűség, a nervus
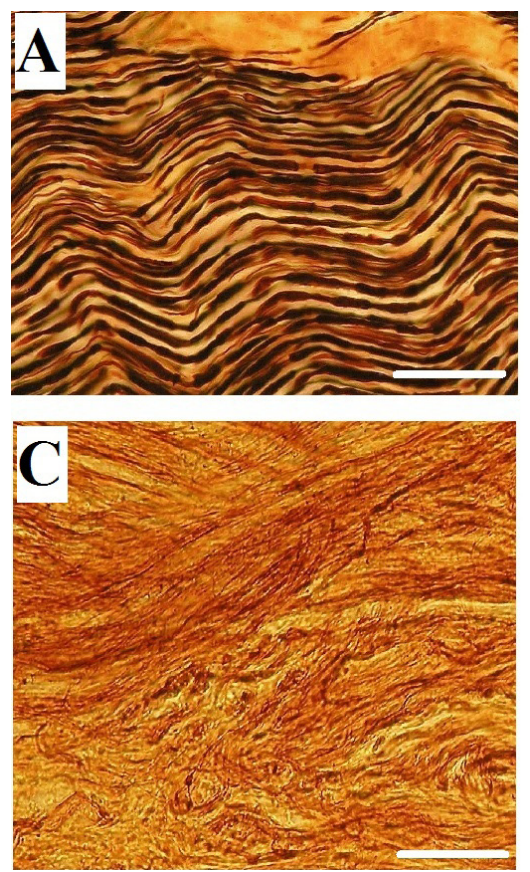

ischiadicuson a sérüléstől distalisan a kontrollcsoporthoz képest (I. csoport) csak 45,2\% volt (II. táblázat).

Az NGF-fel való kezelés eredményeképpen az idegrostok regenerációja szignifikánsan emelkedett, a regeneratív neuromában és a distalis szakaszon egyaránt. A proximalis és a distalis varrat területén az idegrostok hosszirányú, és a károsodott ideghez képest kisebb gyakorisággal lẹresztirányú, valamint visszal. kanyarodó idegrost elrendeződést mutattak. A gliákból álló hegszövet kifejezetten kevesebb volt a kontrollcsoporthoz képest (III csoport), a regeneráció hatékonysága 38,1\%-kal nőtt (2. ábra).

A lokálisan alkalmazott PRP mind a graftban, mind a distalis végen a regeneráció mértékét fokozta, ennek hatékonysága a $80 \%$-ot is elérte, ez az érték 38,6\%-kal magasabb, mint a NGF-fel kezelt csoport esetében tapasztalható. A neuromában és a distalis varrat területén a myelinizált axonok és a véredények sűrűsége növekedett, a gliákból álló hegszövet aránya pedig csökkent.
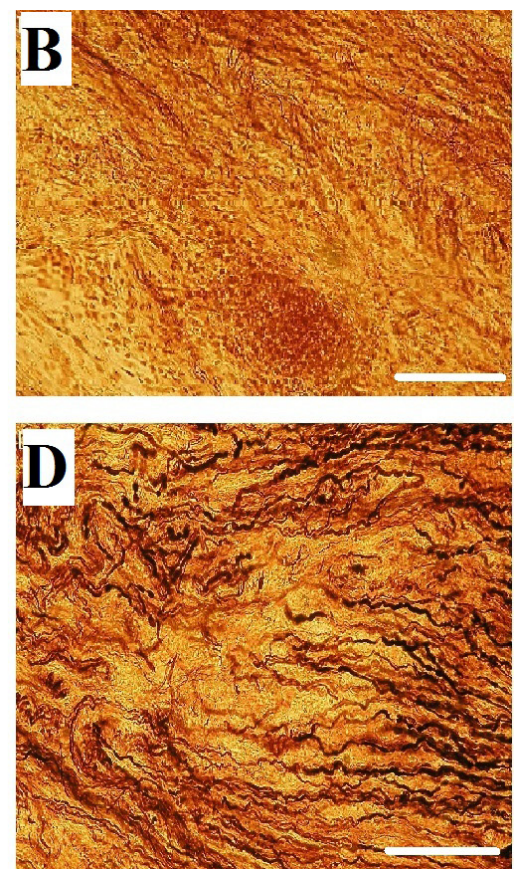

2. ábra Patkány nervus ischiadicus metszet fénymikroszkópos képe, ezüst impergnációval, az end-toend idegvarrat distalis részéből. Kontrollcsoport (A), autografton neuroma (B); idegregeneráció képe, idegvarrott követően NGF használata mellett (C) és PRP használata mellett (D). Jelölö vonal = $200 \mu \mathrm{m}$ 


\begin{tabular}{|c|c|c|c|c|c|c|}
\hline & & Kontroll & $\begin{array}{l}\text { Ischiadicus } \\
\text { átmetszés }\end{array}$ & Idegvarrat & $\begin{array}{l}\text { Idegvarrat } \\
+ \text { NGF }\end{array}$ & $\begin{array}{c}\text { Idegvarrat } \\
+ \text { PRP }\end{array}$ \\
\hline \multirow{2}{*}{$\begin{array}{c}\text { Teljes axon } \\
\text { sürüség/mm² }\end{array}$} & proximalis & \multirow[t]{2}{*}{$10731.0 \pm 416.9$} & $8247.1 \pm 452.4$ & $8734.4 \pm 700.8$ & $9127.2 \pm 654,2$ & $9361.9 \pm 687.7$ \\
\hline & distalis & & - & $4860.4 \pm 443.6$ & $6714.2 \pm 699.8$ & $8591.8 \pm 558.3$ \\
\hline \multirow{2}{*}{$\begin{array}{c}\text { Distalis axon } \\
\text { regeneráció \% }\end{array}$} & kontroll & 100 & - & 45.2 & 62.5 & 80.0 \\
\hline & idegvarrat & \multicolumn{2}{|c|}{-} & 100 & 138.1 & 176.7 \\
\hline \multirow[t]{3}{*}{ *p-érték } & kontroll & - & $<0.001$ & $<0.001$ DOI & $10,2<2,0.01$ & $015 .<6.001$. \\
\hline & idegvarrat & \multicolumn{3}{|c|}{-} & $p>0.05$ & 0.045 \\
\hline & $\begin{array}{l}\text { idegvarrat } \\
+\mathrm{NGF}\end{array}$ & \multicolumn{4}{|c|}{-} & $<0.01$ \\
\hline
\end{tabular}

\section{Az izomszövet károsodásának biokémiai vizsgálata}

A hosszú ideje denervált izom regenerációját jelzi, az aminosavak összmennyiségek változása és az esszenciális, valamint a nem eszszenciális aminosavak aránya. A denervált izomban az összfehérje mennyiség (kötött aminosavak) $34,8 \%$-kal csökkent a kontrollcsoporthoz képest. Az idegrekonstrukción átesett csoport esetén a kötött aminosavak menynyisége 35,7\%-kal növekedett, míg az NGF kezelés esetén 31,9\%-kal, a PRP kezelés hatására 38,6\%-kal növekedett ez az érték. A esszenciális aminosavak teljes mennyisége a kontrollcsoport és a III. csoport között statisztikailag nem mutatott szignifikáns különbséget. Az aminosavak mennyiségi megoszlását a 3. ábra mutatja.

A szabad aminosavak mennyisége más megoszlást mutatott. A szabad aminosavak mennyisége nem mutatott szignifikáns eltérést a kontrollcsoporthoz képest, amely arra utal, hogy a szabad aminosavakból történő fehérjeszintézis és a fehérjelebontás kölcsönösen kiegyenlítik egymást.

A III. csoportban, ahol idegrekonstrukció történt, a szabad aminosavak szintjében egy határozott 78,6\%-os $(p<0,001)$ csökkenés következett be, amelyhez képest az NGF és PRP kezelés hatására ez a szint átlagosan csak 16,5\%-kal csökkent tovább, amely arra utal, hogy a szabad aminosavak a fehérjeszintézisben, és más metabolikus folyamatban felhasználásra kerültek (4. ábra). Meg kell azonban jegyezni, hogy az NGF és PRP kezelés hatására a szabad aminosavak közül az L-cisztein szintje csökkent legnagyobb mértékben, mivel az a szövetek antioxidatív, metabolikus és energiatermelő folyamataiban felhasználásra került.

A neurotomián átesett és az autografttal rekonstruált csoportok között a teljes zsírsav mennyiségben nem volt eltérés, azonban a rövid és hosszú láncú zsírsavak aránya megváltozott. A denervált izmokban a C4-C13 zsírsavak mennyisége csökkent, a C14, C20 és C20:1 mennyisége megnőtt. Az NGF és PRP kezelés a C4-14 zsírsavszintézist a 4,3-5,1-szeresére növelte (5. ábra). A telített és telítetlen zsírsavak mennyiségben a kontroll csoporthoz képest nem volt jelentős eltérés.

$\mathrm{Az}$ elektrolit háztartásban bekövetkezett változások közül a kalciumszint a denervált izmokban 6,1\%-kal csökkent ( $p<0,001)$, az idegrekonstrukciót követően a kalcium 20,9\%-kal csökkent, PRP kezelés mellett 26,2\%-kal, az NGF kezelés mellett 45,6\%-kal csökkent (6. ábra). Az elektrolit háztartásban bekövetkező változások fontos szerepet játszanak a sejtek energiatermelő folyamataiban, az elektrolit szintek csökkenése, mint a foszfát, kálium és kalcium, az ATP termelés csökkenéséhez vezethet. Az izomzatot ért súlyos sérülések heterotop ossificatiót eredményezhetnek, amely az elektrolit háztartás megváltozását okozhatja, azonban ennek pontos mechanizmusának felderítésére további vizsgálatok szükségesek (25). 


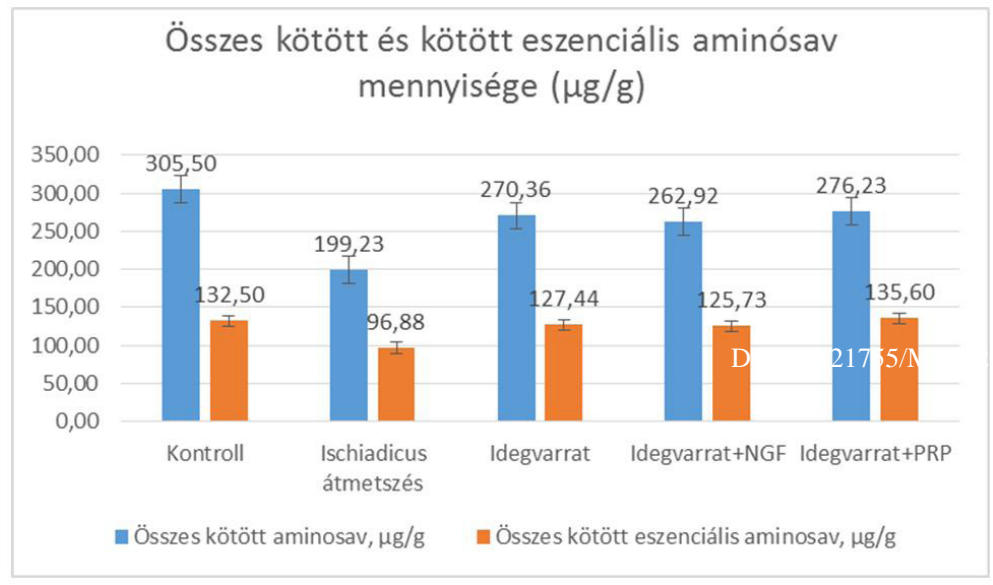

3. ábra Összes kötött és kötött eszenciális aminósav mennyisége

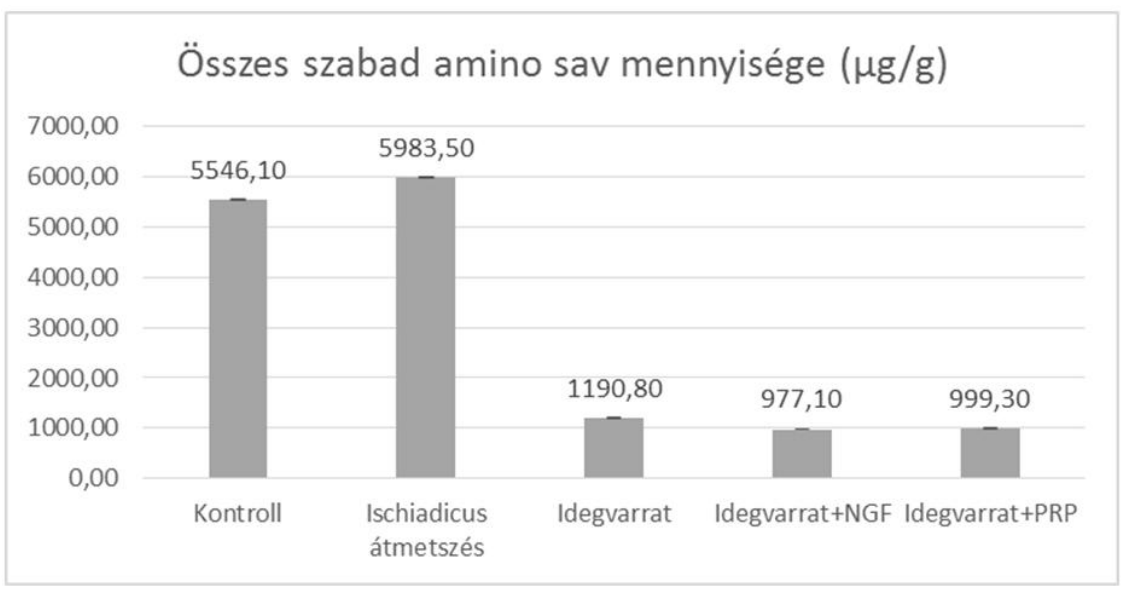

4. ábra Összes szabad aminosav mennyisége

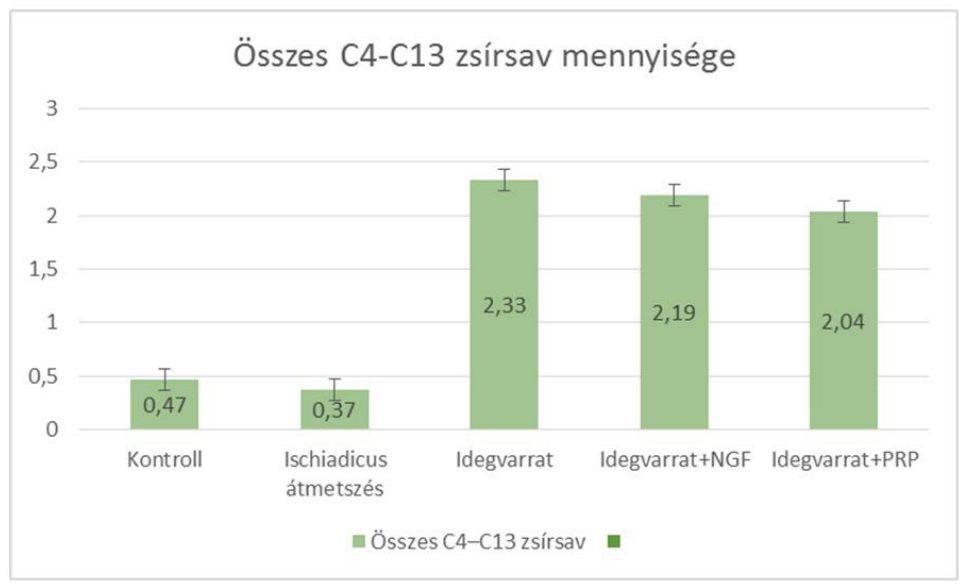

5. ábra Összes C4-C13 zsírsav mennyisége 


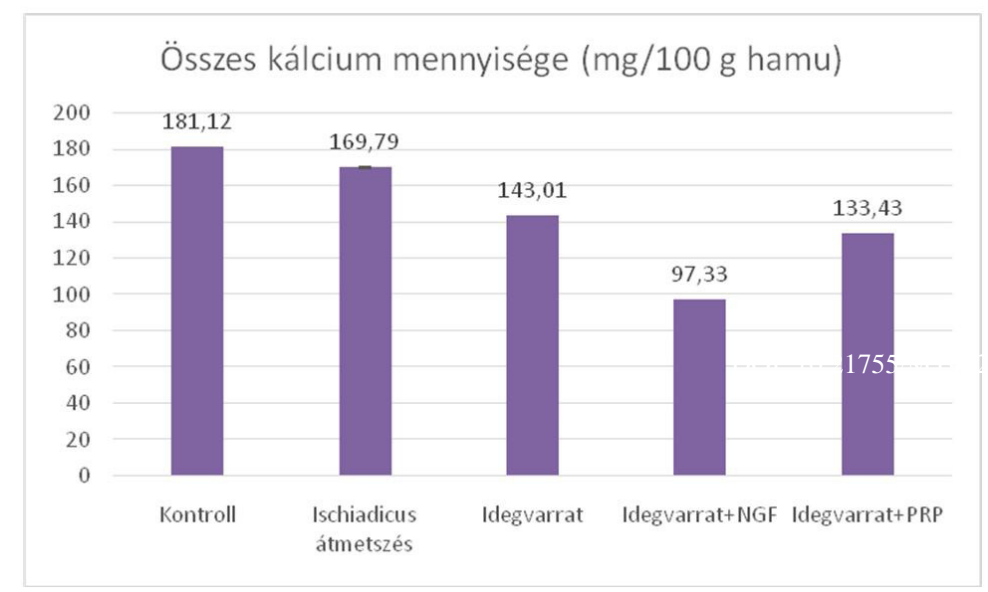

\section{MEGBESZÉLÉS}

Az irodalomban ismeretes, hogy a károsodott perifériás idegekben és a vázizomzatban, strukturális és funkcionális változások következnek be (15). Az idegsérülések helyreállításának eredményeit javító kutatások legnagyobbrészt a kéz sérült idegeivel foglalkoznak, amelyben a hazai kutatók is számos eredményt értek el, mindezzel világszínvonalúvá téve a magyar kézsebészetet $(14,16,23)$.

A kísérleteink során bizonyítottuk, hogy a perifériás idegkárosodás következtében kialakuló izomdegeneráció során megbomlik a sejtek fehérje, lipid és elektrolit metabolizmusa. A fehérje metabolizmusban bekövetkező zavarok, proteolízist, és az ebből származó eszszenciális aminosavak felszaporodását eredményezi, a zsírsav metabolizmus változásának eredménye a telítetlen $\Omega 3,6,9$ zsírsavak felhalmozódása. Az újabb tanulmányok kimutatták, hogy a lipid metabolizmus, és a lipid peroxidáció fontos szerepet játszanak a károsodott izomszövetben lejátszódó patológiás és a regeneratív folyamatokban (17). A zsírsav metabolizmusban bekövetkező változások kevésbé ismertek, így az ebben kialakult változások gyakorlati jelentősége ma még kevésbé ismert, mivel nem állnak rendelkezésre hasonló adatok más szervek vagy szervrendszerek esetében. Kísérleteinkben az idegrekonstrukció csökkentette a zsírsavak és az aminosavak katabolizmusát, növelte a fehérjeszintézist, föként a rövidláncú zsírsavakét, és gátolta az eszszenciális molekulák kiválasztását a sejtekből. A viszonylag hosszú ideig denervált izmok esetén, az idegrekonstrukciót követően az NGF és PRP kezelés hatására az addigi katabolikus folyamatok szignifikánsan anabolikus irányba változnak, amelyet az alkalmazott kezelés az idegvarrathoz képeset még tovább fokoz. A PRP az NGF-hez hasonlóan megelőzni az izomszövetben kialakuló destruktív folyamatokat, segíti a perifériás idegregenerációt, a károsodott vázizomzatban a szabad aminosavakból történő fehérjeszintézist gyorsítja, a lipid metabolizmust aktiválja és az izomsejtekből kalcium ionok eltávolítását serkenti. A denervált izomsejtek kalcium háztartásában bekövetkező változások hátterében álló folyamatok intenzíven kutatott terület (27). Kísérleteinkben az idegrekonstrukciót követő kalciumszint csökkenésének hátterében a különböző kalcium mediálta kaszkádokban való felhasználás állhat.

Az idegrekonstrukciót követő regeneráció elősegítésének egyik fontos eszköze lehet a thrombocyta gazdag plazma alkalmazása az autografttal való idegrekonstrukció esetén, mivel fokozza a metabolikus instabilitás helyreállitását, ezzel minőségi strukturális és funkcionális regenerációt eredményez.

A későbbiekben talán az idegvarratok esetén is rutinszerúen alkalmazhatjuk a saját thrombocyta gazdag plazát, meggyorsítva ezzel a funkció helyreállítását, amely hozzájárulhat a betegek gyorsabb rehabilitációjához, ezáltal a munkában való visszatérés is felgyorsul. A sérültek hamarabb lehetnek újra aktív tagjai a társadalomnak, ezáltal kevésbé terhelik az amúgy is túlterhelt szociális hálót. 


\section{IRODALOM}

1. Ali Engür M., Engür D.: Platelet-rich plasma for patent ductus arteriosus: an orthopaedic surgeon's perspective. Cardiol. Young, 2014. 24. (3): 385-387.

2. Bain J. R., Mackinnon S. E., Hunter D. A.:Functional evaluation of complete sciatic, peroneal, and posterior tibial nerve lesions in the rat. Plast. Reconstr. Surg. 1989. 83: 129-138.

3. Cheesborough J. E., Souza J. M., Dumanian G. A., Bueno R. A. Jr.: Targeted muscle reinnervation in the initial management of traumatic upper extremity amputation injury. Hand, 2014. 9. (2): 253-257.

4. Council of Europe: European Convention for the protection of vertebrate animals used for experimental and other scientific purposes (Provisions of the Protocol ETS No. 170.). 2009. Retrieved from http://conventions.coe.int/treaty/en/treaties/ html/123.htm

5. Delaviz H., Joghataie M., Mehdizadeh M., Bakhtiyari M., Nobakht M., Khoei S.: Transplantation of oljactory mucosa improve functional recovery and axonal regeneration following sciatic nerve repair in rats. Iranian Biomedical Journal, 2008. 12. (4): 197-202.

6. Emel E., Ergün S. S., Kotan D., Gürsoy E. B., Parman Y., Zengin A., Nurten A.: Effects of insulin-like growth factor-I and platelet-rich plasma on sciatic nerve crush injury in a rat model. J. Neurosurg. 2011. 114. (2): 522-528.

7. Fabrizio P. A., Clemente F. R.: Anatomical structure and nerve branching pattern of the human infraspinatus muscle. J. Bodyw. Mov. Ther. 2014. 18. (2): 228-232.

8. Hamid M. S., Mohamed Ali M. R, Yusof A., George J.: Platelet-rich plasma (PRP): an adjuvant to hasten hamstring muscle recovery. A randomized controlled trial protocol. BMC Musculoskelet. Disord. 2012. 13: 138.

9. Hamid M. S., Yusof A., Mohamed Ali M. R.: Platelet-rich plasma (PRP) for acute muscle injury: a systematic review. PLoS One. 2014. 9. (2): e90538.

10. Harms P. G., Ojeda S. R.: A rapid and simple procedure for chronic cannulation of the rat jugular vein. J. Appl. Physiol. 1974. 36. (3): 391-392.

11. Hernán Martínez J., Sánchez A., Torres O., Palermo C., Santiago M., Figueroa C., Trinidad R., Mangual M., Gutierrez M., González E., Miranda Mde L.: Abrupt onset of muscle dysfunction after treatment for Grave's disease: a case report. Bol. Asoc. Med. P. R. 2014. 106. (1): 40-42.

12. Hsu W. K., Mishra A., Rodeo S. R., Fu F., Terry M. A., Randelli P., Canale S. T., Kelly F. B.: Platelet-rich plasma in orthopaedic applications: evidence-based recommendations for treatment. J. Am. Acad. Orthop. Surg. 2013. 21. (12): 739-748.

13. Ijkema-Paassen J., Jansen K., Gramsbergen A., Meek M. F.: Transection of peripheral nerves, bridging strategies and effect evaluation. Biomaterials, 2004. 25 (9): 1583-1592.

14. Józsa L., Renner A., Sántha E., Réffy A.: Az emberi kézizmok elváltozásai mozgatóideg sérülés után. Morph. Igazs. Orv. Szle. 1984. 24: 31-39.

15. Józsa L., Renner A., Sántha E.: Az emberi vázizomzat ultrastrukturális elváltozásai ideg- és ínsérülések után. Magyar Traumatológia Ortopédia Helyreállitó Sebészet, 1977. 20: 47-56.

16. Kovácsy Á.: A sérült ideg regenerációjának vizsgálata a kézen. Kísérletes és klinikai vizsgálatok. Kandidátusi értekezés. Pécs, 1994.

17. Laforêt P., Vianey-Saban C.: Disorders of muscle lipid metabolism: diagnostic and therapeutic challenges. Neuromusc. Disord. 2010. 20. (11): 693-700.

18. Le Nail L. R., Bacle G., Marteau E., Corcia P., Favard L., Laulan J.: Isolated paralysis of the serratus anterior muscle: Surgical release of the distal segment of the long thoracic nerve in 52 patients. Orthop. Traumatol. Surg. Res. 2014. 100. (4. Suppl): 243-248.

19. Lichtenfels M., Colomé L., Sebben A. D., Braga-Silva J.: Effect of platelet rich plasma and platelet rich fibrin on sciatic nerve regeneration in a rat model. Microsurgery, 2013. 33 (5): 383-390.

20. Moore S.: The chromatographie of aminoacids on sulfonated polystyrene resins. J. Biol. Chem. 1951. 192: 2830-2839.

21. Nestares T., Barrionuevo M., López-Frías M., Vidal C., Urbano G.: Effect of different soaking solutions on nutritive utilization of minerals (Calcium, Phosphorus, and Magnesium) from cooked beans (Phaseolus vulgaris L.) in growing rats. J. Agric. Food Chem. 2003. 51. (2): 515-520.

22. Nichols C. M., Brenner M. J., Fox I. K., Tung T. H., Hunter D. A., Rickman S. R., Mackinnon S. E.: Effects of motor versus sensory nerve grafts on peripheral nerve regeneration. Exp. Neurol. 2004. 190. (2): 347-355.

23. Renner A., Cserkuti F., Rutek Zs., Szentirmai A.: Az idegtranszplantációk késői eredményei a felső végtagon és a kézen. Magyar Traumatológia Ortopédia Kézsebészet Plasztikai Sebészet, 2014. 57. (2-3): 81-88.

24. Sukegawa K., Kuniyoshi K., Suzuki T., Ogawa Y., Okamoto S., Shibayama M., Kobayashi T., Takahashi K.: An anatomical study of transfer of the anterior interosseous nerve for the treatment of proximal ulnar nerve injuries. Bone Joint J. 2014. 96-B. (6): 789-794.

25. Tomera J. F., Lilford K.: Calcium and skeletal muscle: a multiple regression on signal transduction mechanisms in burn trauma. Methods Find Exp. Clin. Pharmacol. 1993. 15. (7): 471-482.

26. Varejao A. S., Cabrita A. M., Meek M. F., Bulas-Cruz J., Melo-Pinto P., Raimondo S., Geuna S., Giacobini-Robecchi M. G.: Functional and morphological assessment of a standardized rat sciatic nerve crush injury with a non-serrated clamp. J. Neurotrauma. 2004. 21. (11): 1652-1670. 
27. Vinciguerra M., Musaro A., Rosenthal N.: Regulation of muscle atrophy in aging and disease. Adv Exp Med Biol. 2010. 694: 211-33.

28. Wood M. D., Kemp S. W., Weber C., Borschel G. H., Gordon T.: Outcome measures of peripheral nerve regeneration. Ann. Anat. 2011. 193. (4): 321-333.

\section{Dr. Tóth Zoltán}

Siófoki Kórház-Rendelőintézet

8600 Siófok, Semmelweis u. 1.

zoltan.toth.dr@gmail.com 